\title{
Garments and Shrouds of Egyptian and Nubian Pilgrims from Qasr el-Yahud, Ninth Century CE
}

Qasr el-Yahud, situated on the west bank of the Jordan River nearby Jericho, features the Monastery of Saint John the Baptist, believed to be the traditional site of the Baptism of Jesus1 and has a centuries-long tradition of 'washing of the lepers'. Byzantine and Medieval authors attributed the waters of the Jordan river a special power to heal lepers who bathed in them, especially at the spot where Jesus was baptized.

After the site became sacred, traditions developed that were associated with the holy features of the water and its curative properties. When the emperor Constantius became ill, he asked to bath in the Jordan. In 1983 a rescue excavation at the site revealed thirty-four skeletons, probably representing a hospital population with cases of tuberculosis, leprosy and facial disfigurement. Such individuals travelled enormous distances, attracted to the site in the hope of washing away their illness. Anthropological evidence indicates that the individuals were probably Egyptian in origin, while structural analysis of the skulls proved that some were Nubian. They were buried in a Christian manner, lying on their backs, facing the rising sun. Some of the burial customs at this site, such as placing seeds from the Egyptian Balsam tree (Balanites Aegyptiaca) in the hands of the deceased, conform to Egyptian traditions.

The arid climate of the Judean Desert helped to preserve 250 textiles, among them many examples comprising two different textiles or more sewn together or patched one on another. Radiocarbon dating of the textiles placed the date in the eighth to ninth centuries (787-877 CE). The textiles are made of linen and cotton, sometimes decorated with wool tapestry, brocade and selfbands. They include many cut-to-shape tunics except one which is woven-to-shape, head coverings, bandages and shrouds. This research combines historic sources, anthropological and botanic evidence, burial practices with the textiles. The material is of great importance because it gives us idea about the burial costumes used by Christians at the late Islamic period. In addition, those are the only textiles from this period found in Israel. 